\title{
SINTESIS DAN KARAKTERISASI NANOKOMPOSIT KONDUKTIF NANOFIBER
}

\section{SYNTHESIS AND CHARACTERIZATION OF CONDUCTIVE COMPOSITE NANOFIBER}

\author{
Muhamad Nasir \\ Pusat Penelitian Kimia Lembaga Ilmu Pengetahuan Indonesia \\ Jalan Cisitu Sangkuriang Bandung 40135 \\ Email: mnasir71@yahoo.com
}

Diterima : 29 April 2013, Direvisi : 10 Mei 2013, Disetujui : 30 Mei 2013

\begin{abstract}
ABSTRAK
Telah dibuat nanokomposit konduktif polianilin (PANI) / polivinyliden fluoride (PVDF) nanofiber dengan menggunakan teknikco-axialelektrospining. Proses pembuatan konduktif komposit nanofiber dan morfologinano fiberyang terbentuk sangat dipengaruhi oleh konsentrasi larutan PVDF dan jenis pelarut yang digunakan. Pada konsentrasi polimer yang rendah akan terbentuk nanofiber berupa bead sedangkan pada konsentrasi polimer yang lebih tinggi akan terbentuk nanofiber dengan sempurna. Hasil analisis spectrum FTIR menunjukan struktur Kristal PVDF dalam nanokomposit nanofiber didominasi oleh Kristal $\beta$ fasa. Nanokomposit konduktif nanofiber mempunyai potensi aplikasi yang sangat penting untuk sensor, aktuator, dan filter udara.
\end{abstract}

Kata kunci : Nanokomposit konduktif nanofiber, co-axial elektrospinning, polianilin/pvdfnanofiber

\section{ABSTRACT}

Conductive composite polyaniline/PVDF nanofiber has been synthesized by using co-axial electro spinning. Morphology and diameter of nanofiber was influenced by $P V D F$ polymer concentration and the type of solvent. Beaded nanofiber was formed at lower polymer concentration. On the contrary, free beaded nanofiber was formed at higher polymer concentration. Result of FTIR analysis showed that PVDF crystal structure was dominant by $\beta$-phase crystal structure. Conductive composite nanofiber has potential application in sensor, actuator and air filter.

Keywords: Conductive composite nanofiber, co-axial electrospinning, polyanilinelpvdf composite nanofiber

\section{PENDAHULUAN}

Saat ini perkembangan nanosains dan nanoteknologi sangat cepat dan menjadi perhatian utama kalangan akademik dan industri. Perubahan ukuran material dari skala makro ke skala nano menyebabkan perubahan sifat-sifat material dan akhirnya akan berpengaruh pada kinerja alat ataupun produk yang menggunakannya ${ }^{(1)}$. Salah satu topik penelitian yang banyak dilakukan saat ini adalah pengembangan material nano seperti nanofiber dan nanopartikel dengan menggunakan teknologi elektrospinning. Keunggulan nanofiber dibandingkan dengan fiber konvensional adalah mempunyai luas permukaan spesifik yang sangat luas, sangat ringan, bentuk yang fleksibel, mengurangi ruang yang dibutuhkan dalam aplikasi, mampu menembus batas kinerja optimum material konvensional, mempunyai nilai ekonomi yang sangat tinggi ${ }^{(2)}$. Nanofiber mempunyai potensi aplikasi dalam bidang energi, medisin, bioteknologi, pemurnian air dan lain-lain.

Elektrospinning adalah salah satu cara yang ampuh untuk membuat nanofiber dan nanopartikel. Secara sederhana proses elektrospinning adalah sebagai berikut: larutan polimer di charge dengan listrik DC tegangan tinggi; peningkatan voltase akan mempengaruhi dan mendistorsi droplet pada ujung nozel, jika tegangan yang diberikan mampu mengatasi tegangan permukaan (surface tension) larutan maka droplet pada ujung nozzle akan pecah dan akan membentuk aliran lurus dari larutan polimer (polymer jet). Selanjutnya pada saat dan jarak tertentu akan terjadi instabilitas dari polimer jet. Pada saat aliran polimer menunju kolektor akan terjadi penguapan pelarut dan akhirnya akan terjadi solidifikasi polimer menjadi nanofiber dikolektor yang terhubung dengan ground tegangan listrik ${ }^{(3)}$.

Material komposit dibuat dengan tujuan untuk mendapatkan sifat gabungan dari material penyusunnya, peningkatan sifat-sifatnya serta mengontrol nilai ekonomisnya. Polianilin adalah polimer yang bersifat konduktif. Sedangkan PVDF adalah sebuah material yang sangat penting dalam dunia indutri karena sifat kimia dan fisiknya yang baik. PVDF 
mempunyai beberapa fasa kristal, seperti fasa alfa $(\alpha)$, beta $(\beta)$ dan gama $(\gamma)^{\left({ }^{(4)}\right.}$. Fasa $\alpha$ tidak mempunyai sifat listrik, sedangkan fasa $\beta$ dan $\gamma$ mempunyai sifat listrik. Fasa $\beta$ PVDF dengan sifat listriknya seperti piezoelektrik, pyroelektrik sangat penting dalam apliksi industri. Dalam pembuatan nanokomposit konduktif PVDF/PANI nanofiber pengontrolan bentuk kristal dari PVDF adalah sesuatu yang sangat penting ${ }^{(5)}$.

Tujuan penelitian adalah untuk membuat nanokomposit konduktif PVDF/PANI nanofiber, pengontrolan morfologi dan strukturnya dengan teknologi elektrospinning.

\section{BAHAN DAN METODA}

\section{Bahan}

Bahan-bahan kimia yang digunakan: polyaniline (PANI) (Merck), PVDF (Sigma), N-N DMAc (Sigma), aceton (Sigma), SDS (Sigma).

\section{Peralatan}

Mesin elektrospinning dengan co-axial nozel, FESEM(JEOL) dan FTIR (Nicolet).

\section{Metoda}

\section{Larutan untuk elektrospinning}

Polianilin dilarutkan dengan asam asetat dengan berbagai variasi konsentrasi dan diaduk sampai larut dan kemudian disaring dengan mikrofilter. PVDF dan SDS dilarutkan dengan pelarut N-N DMAc secara bersama-sama dan diaduk secara terus menerus pada suhu $60^{\circ} \mathrm{C}$. Setelah polimer sempurna larut, kemudian larutan didiamkan untuk menghilangkan udara yang terperangkap.

\section{Pembuatan nanofiber}

Larutan PVDF dipasang pada larutan umpan untuk bagian luar (shell) sedangkan larutan PANI dihubungkan dengan nozel bagian dalam (core). Kecepatan aliran larutan PVDF dan PANI diatur untuk mendapatkan kondisi optimal. Jarak antara nozel dan kolektor, kemudian voltase yang digunakan diatur untuk mendapatkan kondisi yang optimum.

Nanofiber yang terbentuk dikeringkan dalam desikator vacuum untuk menghilang sisa pelarut dan pengotor.

\section{Karakterisasi}

Morfologi nanofiber dikarakterisasi dengan menggunakan FESEM (JEOL) dan struktur dari PVDF diidentifikasi dengan FTIR (Nicolet).

\section{HASIL DAN PEMBAHASAN}

\section{Pengaruh konsentrasi PVDF polimer pada morfologi nanofiber}
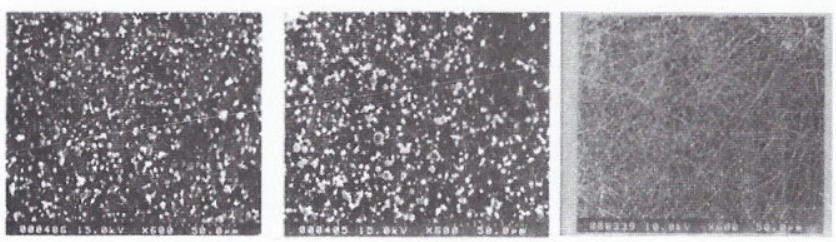

Gambar 1. Perubahan morfologi dari nanokomposit konduktif nanofiber dengan variasi konsentrasi PVDF. A) PVDF $=20 \% \mathrm{w} / \mathrm{w}, \mathrm{B})$ PVDF $=26 \% \mathrm{w} / \mathrm{w}$ dan C). PVDF $=33 \% \mathrm{w} / \mathrm{w}$. Sedangkan konsentrasi PANI tetap ( $1 \mathrm{t} \% \mathrm{w} / \mathrm{w})$.

Gambar 1 menunjukan morfologi dari nanokomposit konduktif nanofiber. Pada konsentrasi larutan PVDF 20\% terbentuk nanopartikel. Peningkatan konsentrasi PVDF menjadi 26\% terbentuknya beaded nanofiber. Pada konsentrasi PVDF $33 \%$ terbentuk nanofiber secara sempurna. Fenomena perubahan morfologi berhubungan dengan pengaturan molekul polimer dalam larutan. Pada konsentrasi rendah polimer dalam larutan berbentuk independent globe, sehingga jika menggunakan larutan ini dalam proses elektrospinning akan terbentuk nanopartikel. Pada konsentrasi polimer sedang akan mulai terjadi interaksi antara globe dalam larutan, pada proses ini akan terbentuk beaded nanofiber. Pada konsentrasi tinggi akan terjadi overlap antar molekul dalam larutan, sehingga akan terbentuk nanofiber secara sempurna ${ }^{(6-9)}$.

\section{Pengaruh campuran pelarut pada morfologi nanofiber}

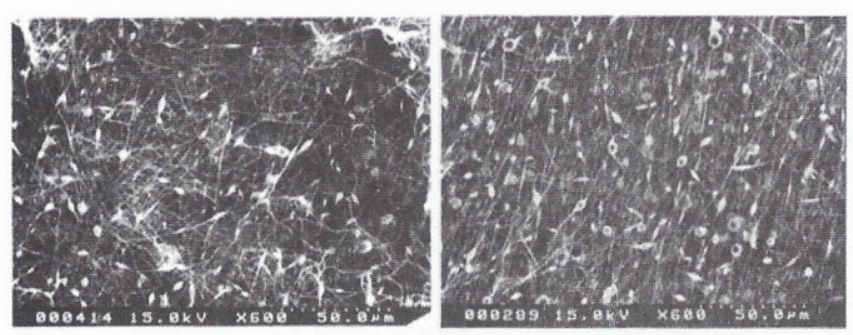

Gambar 2. Perubahan campuran pelarut terhadap morfologi dan bead dari nanokomposit konduktif nanofiber dengan variasi konsentrasi PVDF. (a) PVDF $30 \mathrm{wt} \%$ - laju alir $0.6 \mathrm{ml} / \mathrm{h}-\mathrm{SDS}-05 \mathrm{wt} \%$ - asetone 10 wt \%-PANI 1 wt \%-laju alir $0.008 \mathrm{ml} / \mathrm{h}$ dan (b). PVDF 30 wt $\%$ - laju alir $0.6 \mathrm{ml} / \mathrm{h}$ - SDS- $05 \mathrm{wt} \%$ PANI $1 \mathrm{wt} \%$-laju alir $0.008 \mathrm{ml} / \mathrm{h}$

Gambar 2 adalah morfologi dari nanokomposit konduktif nanofiber dengan campuran pelarut. Terlihat dengan penambahan pelarut aseton maka terbentuk jumlah bead yang lebih banyak. Jumlah bead pada 
proses pembentukan nanofiber tergantung pada sifat larutan, tegangan permukaan, konduktivitas larutan dan tegangan yang digunakan. Aseton bukanlah pelarut yang baik bagi PVDF sehingga dengan mencampurkan aseton dengan N-N DMAc akan menyebabkan terbentuknyaglobe.

\section{Diameter nanofiber}

Dalam pembuatan nanofiber, Pengontrolan konsentrasi larutan polimer adalah salah satu cara yang sangat efektif dalam mengontrol diameter nanofiber. Pada konsentrasi rendah akan didapatkan nanofiber dengan diameter yang lebih kecil, sebaliknya diameter nanofiber yang lebih besar akan didapatkan jika menggunakan polimer konsentrasi besar, dimana hal ini terlihat jelas pada Gambar 1.

\section{Struktur Nanofiber}

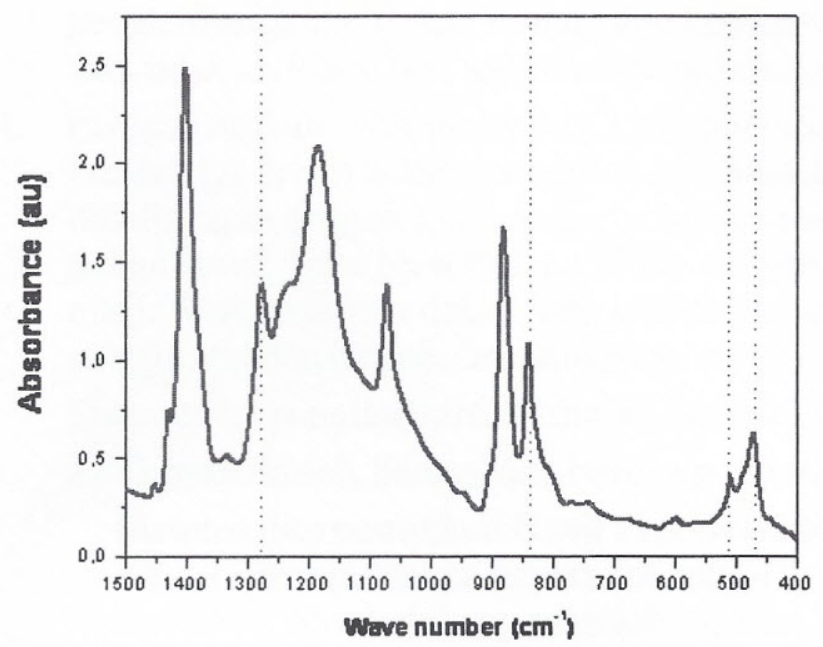

Gambar 3. Spektrum FTIR nanokomposit konduktif PVDF / polyaniline nanofiber

Gambar 3 menunjukan spektrum infra merah dari nanokomposit konduktif PVDF/PANI nanofiber. Spektraum FTIR menunjukan gugus fungsi dari PVDF. PVDF berada pada bagian luar (shell) dari nanofiber. Dari spectrum terlihat puncak serapan spesifik dari fasa $\beta$ PVDF, yaitu pada panjang gelombang $1277 \mathrm{~cm}^{-1}$, $840 \mathrm{~cm}^{-1}, 610 \mathrm{~cm}^{-1}$ dan $472 \mathrm{~cm}^{-1(4-5)}$. Hasil ini menunjukan bahwa kita berhasil mengontrol kristal struktur PVDF dalam system kompositnya. Hal ini berarti sangat penting dalam pengembangan aplikasinya, seperti untuk sensor dan aktuator.

\section{KESIMPULAN}

Proses pembuatan nanokomposit konduktif PVDF/PANI nanofiber sangat ditentukan oleh konsentrasi larutan PVDF. Free beaded nanokomposit konduktifnanofiber didapatkan pada konsentrasi larutan PVDF $33 \%$ w/w. Struktur PVDF dalam nanokomposit konduktif nanofiber yang dominan adalah dalam bentuk kristal fasa $\beta$. Untuk selanjutnya akan diteliti lebih mendalam tentang morfologi dari polianiline dalam inti nanofiber komposit.

\section{DAFTAR PUSTAKA}

1. Y.Dzenis, Science 2004,304 1917-1919

2. S. Ramakrishna, K. Fujihara, Wee-Eong Teo, T. Yong, Z. Ma, and R. Ramaseshan, Material today 2006, 9, 40-50

3. A. Formhals, US Patent no. 1975504 19341002, 1934

4. M. Nasir, H. Matsumoto, T. Danno, M Minagawa, T Irisawa, A. Tanioka, Journal of Polymer Science Part B: Polymer Physics 2006, 44, 779-786

5. M. Nasir, H. Matsumoto, M. Minagawa, A. Tanioka, T. Danno, H Horibe, , Polymer Journal $2007,39,7$

6. MG. McKee, GL. Wilkes, RH. Colby, TE. Long, Macromolecules 2004,37, 1760-1767

7. PG. De Gennes, Macromolecules 1976, 9,587597

8. SL. Shenoy, WD. Bates, HL. Frisch, GE. Wnek, Polymer 2005, 463372-3384

9. Teraoka, Polymer Solutions: An Introduction to physical properties 2002, Willey Intesciences 